\title{
A Factorial Study of Language Impairment of 269 Aphasic Patients with Cerebrovascular Accident
}

\section{(Part II) The Variability of Factor Scores in the Recovery Process of Aphasic Impairments}

by

Sumiko Sasanuma*, Ph. D. and Yoko Fukusako**

from

* Tokyo Metropolitan Institute of Gerontology

** Dept. of Otolaryngology, Tokyo Univ. School of Medicine

The recovery processes of 72 out of the 269 aphasic patients studied in PART I were investigated longitudinally by means of following up the rate (and direction) of the change of each of the five factors obtained in PART I. Measurement was taken of the increase and decrease of the factor scores estimated for each patient. at each of the successive re-testings. The length of the follow-up period ranged from one to 32 months after the initial evaluation.

Each factor seemed to have its characteristic mode of change in time. Factor 1 (the general factor of language behavior) had a tendency to exhibit subnormal scores in the majority of subjects at the initial evaluation, but to show a greatest possibility of improvement for a longest period of time (1.5 years since onset). The rest of the factors tended to be more variable in the kinds of subjects exhibiting subnormal scores as well as in the rate and degree of improvement. The clinical types of aphasia appeared to serve as a crutial variable in predicting the overall patterns of improvement of the five factors in individual patients.

The findings seemed to give a further support for the neuro-physiological interpretation of the five factors suggested in PART I. The necessity of increased specificity in our diagnostic and therapeutic procedures was emphasized, and the possible use of the factor analysis technique for this purpose was reiterated. 


\title{
研究と報告
}

\section{脳血管障害性失語症患者 269 例の言語症状 \\ その因子構造と回復過程について $(2)$}

\author{
失語症状の回復過程に抢ける因子得点の変動
}

\section{笹 沼 澄 子* 福 迫陽子**}

\section{I. 緒 言}

失語症状の回復過程を長期にわたって追跡した 研究は少ない，わずかに Sands ら(1969), Sarno ら（1970 a，1970 b，1971）などによる重篤失語 症患者の追跡研究，および Vignolo (1964) が力 ルテの記録を拠りどころとして “回顧的”にまと めた経過調査などがみられる程度である。こうし た縦断的な研究は，横断的な研究に比べて方法論 上の種々の制約が大きいことも，この種の研究の 乏しい理由の一つであろう。しかし，脳損傷によ

* 東京都老人総合研究所言語聴覚研究室, 東京大 学音声言語研究施設

** 東京大学医学部耳鼻咽喉科学教室

脚註 1)

The Minnesota Test for Differential Diagnosis of Aphasia は 1948 年に，その Research Edition, Form 1 が試作され，17 年後の 1965 年にForm 8 の出版をみた。この間, 総計約 1200 例の失語症患 者についての系統的な観察・追跡研究が行なわれ， その結果を折り込みつつ逐次改訂が重ねられてきた ものであり，その意味で, 経験的・実証的な色彩の 濃い検査法であるといえる.Schuell-笹沼失語症鑑 別診断検查の原著は, Research Edition, Form 7 (1958) であるが，これは Schuell 自身が因子分析 を行なった Form 6 (1955) および 1965 年に出版 された Form 8 と比べて, 二，三の末梢的変更を 除いて検査内容に関する実質的な差はほとんどない といってよい，日本語版への翻案にあたっては，表 面的な逐語訳を排し，原著における個々の検査が， 患者からどのような反応をひき出すことを意図して いるかということに焦点を合わせ，その意図を忠実 に具現しうるような邦語版を作製することを心がけ た.そのために, 原著者と緊密な連絡を保ちつつ, 必要に応じて検査項目の変更・省略・添加（たとえ ば漢字対仮名の問題の導入など）をも行なった.
っていったん障害された言語機能（の種 々の側 面）が，その回復の過程で示す多様な変化とその 相互関係のなかにこそ，失語症の実体の解明につ ながる貴重な情報が含まれていることは疑いな い.

幸いにわれわれは，本研究第 1 部の被験者 269 例中の 72 例について，1 カ月から 36 力月にわた る経過観察を行なら機会を得たので，これらの症 例が示す失語症状の経時的変動の様相を，第 1 部 で抽出された 5 個の因子の追跡をとおしてとらえ ることを試みた。また，Schuell（1964）の分類法 に基づく 5 つの臨床タイプ（表 1 ）が，おのおの どのよらな因子変動のパターンを示すかについて も検討した。

\section{II. 方 法}

\section{対象と方法}

本研究第 1 部における被験者 269 例の失語症患 者のうち Schuell-笹沼失語症鑑別診断検查（試案 II) 脚註 1 ) による評価を 2 回以上受けた 72 例を対 象とした（72 例中 52 例は 2 回，14 例は 3 回，6 例は 4 回の検査を受けた)。初診時すなわち第 1 回の検查時点における年齢分布, 教育年数, 発病 からの経過月数は，表 2 に示すとおりである．経 過観察期間（第 1 回の検查時から最終回の検査時 まで）は平均 9.3 力月（範囲：1力月～32力月）, 検查から検査までの間隔は平均 6.5 力月（範囲： 1 力月 12 カ月) であった。発症から最終回の検 查時（観察期間終了時）までの経過期間は， 1 年 以内が 29 例でもっとも多く $(40.3 \%) ， 1$ 年以上 2 年以内が 21 例 $(29.2 \%), 2$ 年以上 3 年以内が 


単純失語
言語表象の理解と表出に関する言語機能の全般的低下
をきたした状態であり, 知覚, 運動過程の障害を伴わな
い.
予 後
もっとも良好であり, 訓練によって実用的な言語機能
の回復を期待できる.

構音失行を伴う失語

構音失行を合併した失語症で, 通常, 言語機能そのも のの障害も単純失語の場合に比べて重症である.

予 後

回復の速度が全般的に遅く, 音声言語の完全な流暢さ を取戻すことは困難である。しかし訓練に応じて比較的 長期間にわたって改善が続き，実用的に役立つ言語機能 レベルに達する場合も少なくない。

部分的聴覚失認を伴う失語

中枢性の聴覚過程, とくに個々の語音の弁別, 認知の 障害を合併する失語症であり, 言語機能そのものの障害 も, 中等度から重症にわたる。

予 後

不良な場合が多い。

散在病单性失語

60 歳以上の 高齢者に多く, 音声器官の運動機能の障 害, すなわち dysarthria あるいは中枢性の視覚過程の 障害（視空間認知, 視覚一運動の障害など）のいずれか, または両方が合併した失語症である。言語機能そのもの の障害は必ずしも重症ではなく，部分的に保たれている

14 例 $(19.4 \%), 3$ 年以上（最高 6 年 0 カ月） は 8 名 (11.1\%) であった.

これら 72 例のおのおのが 本研究第 1 部におい て抽出された 5 個の因子のそれぞれに対して示す 重みづけ，すなわち因子得点を算出し脚註 2)，こ の因子得点が時間の経過とともに（すなわち検査 を重ねるごとに）どのような変動を示すかを検討 した.

朋註 2)

5 個の因子得点の算出に用いた式は以下のとおり である.

$$
\begin{aligned}
Z_{\alpha}= & \beta_{\alpha 1} X_{1}+\beta_{\alpha 2} X_{2}+\beta_{\alpha 3} X_{3}+\cdots \cdots+\beta_{\alpha 68} X_{68} \\
& Z_{\alpha}: \text { 因子得点 } \\
& \alpha: 1-5 \text { 個の範囲をとる } \\
& \beta_{\alpha} i(i=1,2, \cdots \cdots 68): \text { テストに対する因子 } \alpha \\
& \text { の重みづけ, または係数で, 因子負荷量にほ } \\
& \text { ぼ等しい. } \\
& X_{1}-X_{68}: \text { 下位テストの成績 }
\end{aligned}
$$

場合がある。

予後

全般的な精神機能レベルの低下, 種々の合併症, 訓練 への動機づけの低さなど，言語以外の諸要因に左右され やすい。概して訓練効果があがらず，予後不良な場合が 多い.

\section{全失語（不可逆性失語）}

言語機能全般のほとんど完全な崩壊をきたした重症な 失語症である。

予 後

もっとも不良である。強力な言語訓練を行なっても， 実用的な言語機能の回復は期待しがたい.

表 1 脚註

この表に示した分類と予後の裏づけとしては, Schuell らが 20 年近くにわたり，1000 例以上の失語 症患者について, 包括的な失語症検査を定期的にくり 返しつつ分析を重ねることによって得た龙大なデータ がある。わが国でも，Schuell-笹沼失語症鑑別診断検 査（1963）の作製以来，この分類法を適用して観察を 続けているが, Schuell の主張するょうに各臨床タイ プが回復の全過程を通じて比較的恒常であること（1 つのタイプから他のタイプへ移行することがないこ と）が実証されている.

なお Schuell は合計 7 つの臨床タイプをあげてい るが, その中の 2 つ, 中枢性視覚過程の障害を伴う失 語と, 永続的 dysarthria を伴う失語とは, その定型 例がわが国の症例中にきわめて少ないので，表に含め なかった。

表 2 年齢・教育年数・発病後経過月数 $(\mathrm{N}=72)$

\begin{tabular}{l|c|c|c}
\hline & 年 齢 & 教育年数 & $\begin{array}{c}\text { 発 病 後 } \\
\text { 経過月数 }\end{array}$ \\
\hline 範 囲 & $25 \sim 72$ & $3 \sim 20$ & $3 \sim 64$ \\
平 均 & 52.5 & 10.4 & 12.4 \\
中 央 值 & 53.0 & 10.0 & 6.5
\end{tabular}

\section{III. 結果と解釈}

図 1 (a)〜 (e) は, 72 例の失語症状の経時的推移 を，5個の因子得点の変化としてとらえたもので ある。横軸は経過月数脚註 3 ), 縦軸は因子得点で あり，1本の折れ線は 1 名の症例をあらわす．正 負の符号の位置は, 下位テスト得点と照合して決

\section{脚註 3 )}

経過月数 36 力以上の症例は, 例数が少ないこと, 得点の変動がほとえどみられないことの理由により, 図から省略した。 


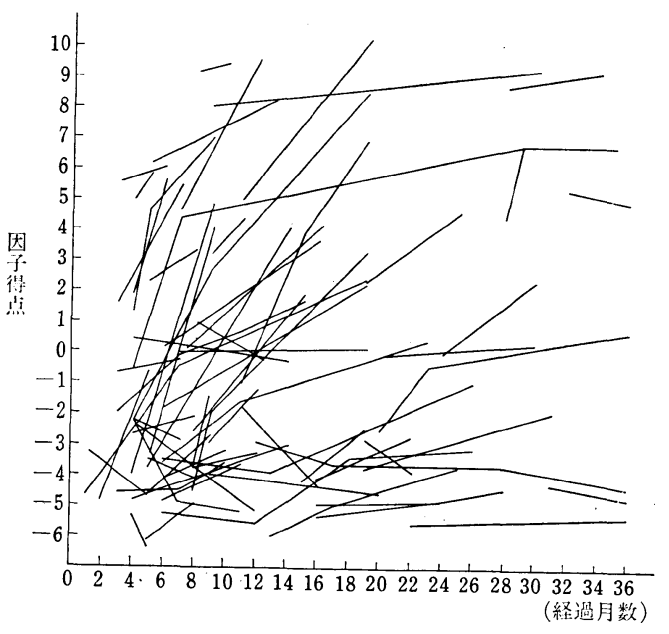

図 1 (a)

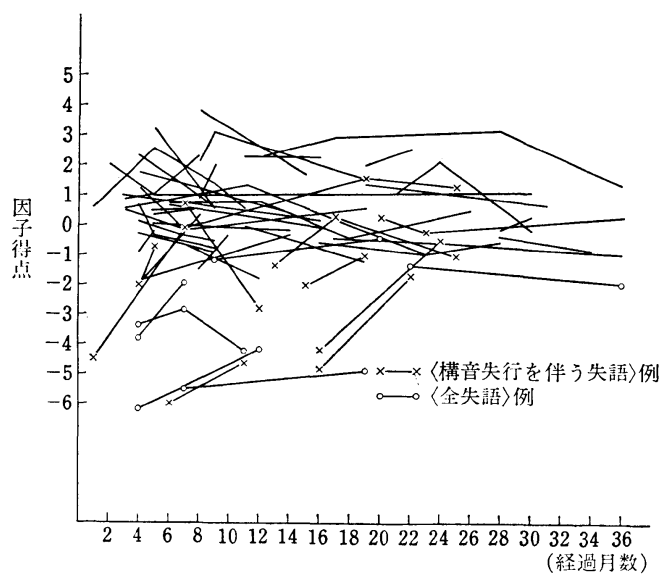

図 I (c)

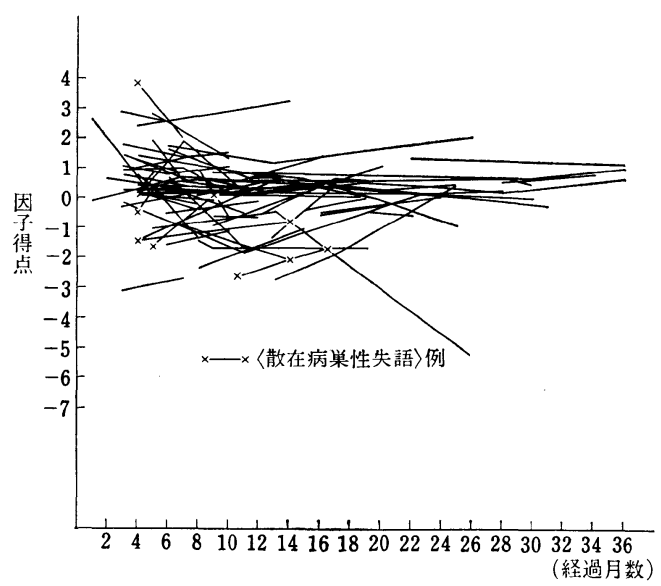

図 I (e)

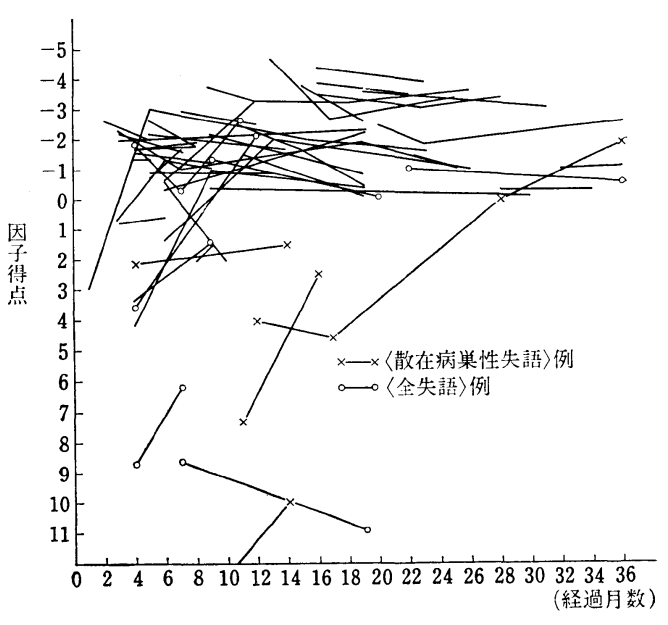

図 1 (b)

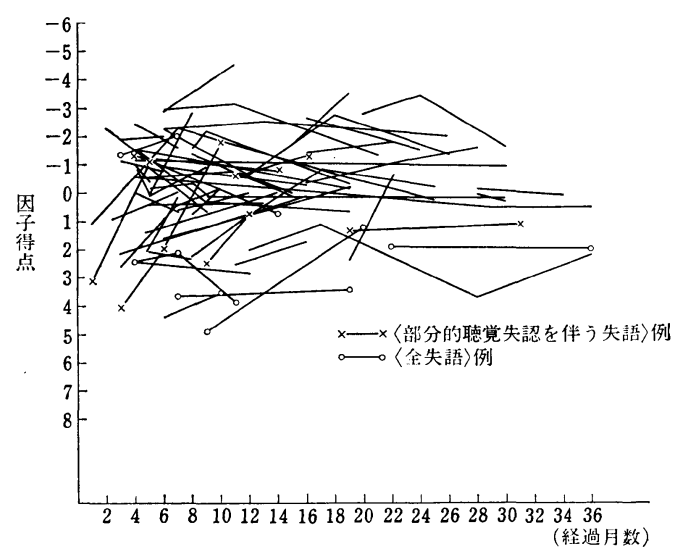

図 1 (d)

定し，図上の点が上にあるほど症状が軽く（すな わち正常に近く)，逆に，下にあるほど明らかな 異常を意味するようにした。

\section{1. 第 1 因子（言語行動の一般因子）の変動}

(図 1 a)

本因子は， 5 個の因子中最大の変動を示し，と くに上昇傾向を示すものが多い，上昇の程度は発 症後 1 年以内がもっとも顕著であり, 2 年目に至 ると, 軽症例（図の上方にあるもの）はひき続き 上昇を続けるが，重症例（図の下方にあるもの） は plateau 状態に近づく傾向がみられる.

次に, このような変動の個人差が, 失語症の種 類によるものであるかどらかを明らかにするため 


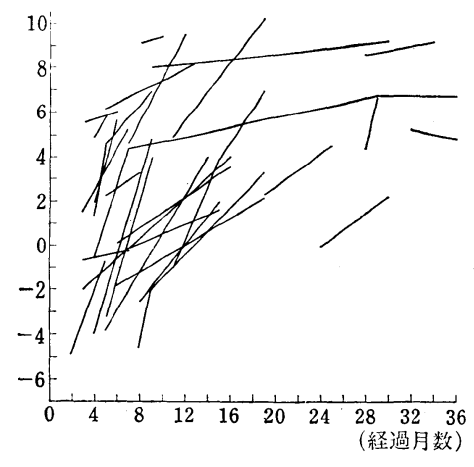

図 2(a)

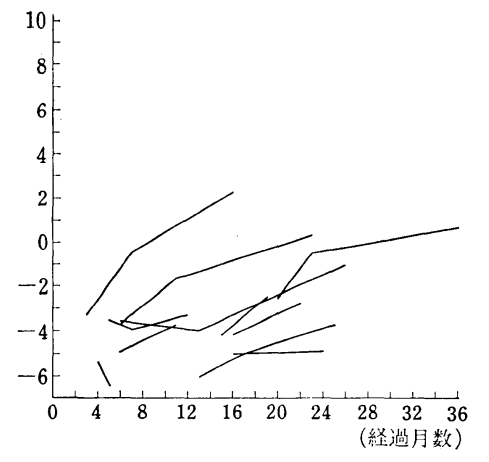

図 2 (b)

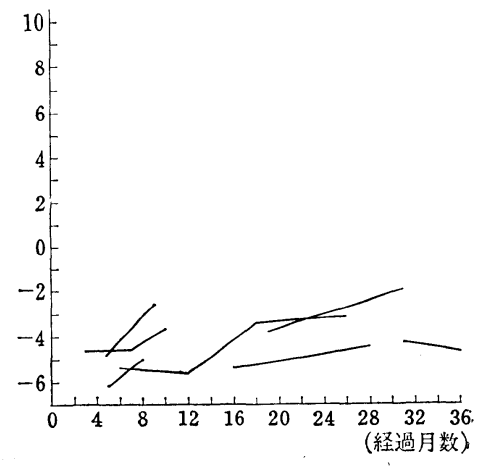

図 2 (c)

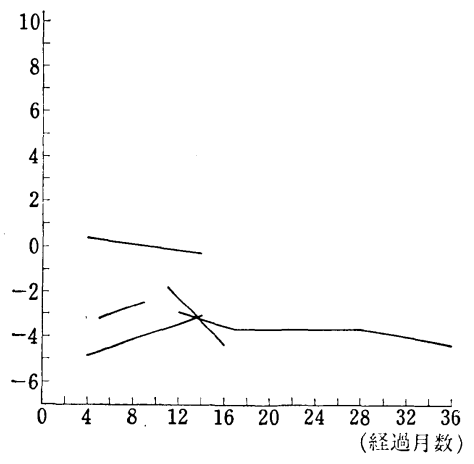

図 2 (d)

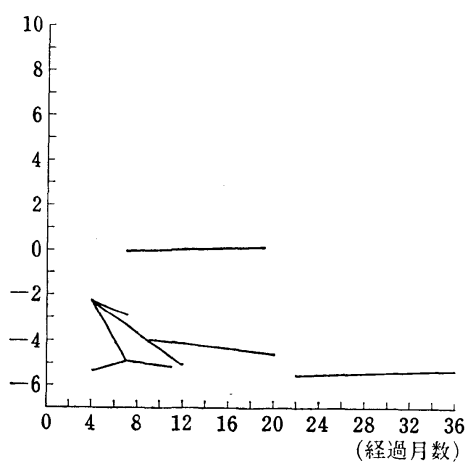

図 2(e)
に, Schuell の分類法に基づく各臨床タイプ別に 得点の変動をまとめてみた（図 $2 \mathrm{a} \sim \mathrm{e}$ ).

単純失語（図 2 a) は，他の群に比べて明らか に高い上昇率を示すものが多く, 構音失行を伴ら 失語（図 $2 \mathrm{~b}$ ) がこれに続く. 部分的聴覚失認を 伴う失語, 散在病巣性失語, 全失語（図 $2 \mathrm{c} \sim \mathrm{e}$ ) においては，上昇傾向がほとんどみられないもの が多数を占める.

すでに第 1 部で指摘したように，本因子は言語 行動の一般因子として失語症の特徵をもっともよ くあらわす因子であり，したがって，この因子に みられる変動は, 失語症状の経時的変動ないし改 善の様相をもっとも敏感に反映すると考えてょい であろう。その意味で臨床タイプによる上記のよ らな変動の差が，おのおののタイプに特有な予後 と，事実きわめてょく一致していることはむしろ 当然であるかもしれない。

\section{2. 第 2 因子（中枢性視覚過程の障害）の変動} (図 $1 \mathrm{~b}$ )
本因子は得点の分布範囲がもっとも広い（十 19.6〜 -4.7) 因子である. 第 1 因子に比べて, （1）折れ線が上限近くに集中していること,

（2）下限に近い明らかな異常を示す例において は，そのほとんどが発症後 1 年以内に急速な上昇 (改善)を示して plateau 状態に達し，その後は ほとんど変動を示さないことなどが特徴である。 このことは，たとえば第 1 因子の場合に比べて， 本因子によって代表されるプロセス（ないしその 障害）が，個体そのものに内在する神経生理学的 条件の支配をより直接的に受けるものであり（言 いかえれば，個体の外部からの働きかけ，すなわ ち環境面の種々の刺激や訓練などによる可逆性が そしく)，したがって，もし改善がみられるとす れば，それはむしろく自然治癒>に負うところが 大であることをあらわしているとみることもでき よう。

臨床タイプ別にみると，この因子に明らかな異 常を示す例は, 主として散在病巣性失語と全失語 
に限られている。しかも，その值が極端に大きい （正常からの逸脱が大きい）ものが多いことが特徴 であり，これらの臨床群を特色づける広範な，ま たは散在的な病巣を反映するものと考えられる.

\section{3. 第 3 因子（構音運動のプログラミング）の 变動（図 $1 \mathrm{c}$ )}

第 3 因子は，第 1 因子に比べて，（1）明らか な異常を示す症例が少ないこと，および（2）こ らした異常を示す少数例にみられる得点の上昇 は，比較的早期に起こる場合が多いこと，の 2 点 において第 2 因子の変動に似ている.

臨床タイプ別にみると，（1）この因子に明ら かな異常值を示すものは構音失行を伴ら失語例と 全失語例に多く, (2) 逆に単純失語例と部分的 聴覚失認を伴う失語例には少ない。（3）散在病 巣性失語例の場合は，一定の傾向を示さず，因子 得点 1.0 の周辺にばらついている。 上記 (1) の 現象は，（a）本因子が代表していると推定される 構音器官の motor programming の障害が, 構音 失行を伴ら失語例の鑑別上の主要な決め手である こと，(b) 全失語例においては，その global な 症状中に当然この構音失行的要因も含まれる可能 性が強いこと，によってそれぞれ説明されると考 えられる。これに対して，単純失語および部分的 聴覚失認を伴う失語の場合には，構音失行を伴わ ないことが分類上の必要条件の一部をなしている ことが，（2）の現象と対応する．（3）の現象， すなわち散在病巣性失語にみられるばらつきは, このタイプが構音失行的要因を随伴する場合とし ない場合とがあるといら臨床事実から当然予想さ れるといえよう。

\section{4. 第 4 因子（中枢性聴覚過程）の変動} (図 $1 \mathrm{~d}$ )

第 2 因子および第 3 因子の場合と同様，本因子 が明確な上昇傾向を示す時期は, 発症後 1 年以内 に汇汇限定され，その後は徐々に減速しながら， きわめてゆっくりとした上昇を続け，1.5 年ごろ に plateau 状態に達する。

本因子に異常を示す症例は，部分的聴覚失認を 伴ら失語と全失語とに属するものが圧倒的に多 い。このことは，（1）本因子の代表する聴覚弁 別・認知の障害が部分的聴覚失認を伴ら失語の鑑
別上の基本条件であること，（2）全失語におい ては，その global な障害の部分症状としてこの ような聴覚過程の障害を含む可能性が高いこと, をそれぞれ反映しているといえよう。これに対し て, 聴覚弁別・認知の障害を伴わない単 純失語 と, こうした聴覚過程の障害の合併を分類上の必 要条件とはしない構音失行を伴う失語とは，いず れも図の上限，すなわち正常域に近いものが多 い。た，この障害を伴う場合とそうでない場合 とがある散在病巣性失語は, 図の中央周辺にばら つく傾向を示している.

\section{5. 第 5 因子（音声器官の運動機能）の变動} (図 $1 \mathrm{e}$ )

第 5 因子は変動の幅がもっとも小さい $(+3.8$ $\sim-5.2$ ) 因子である. 大多数が因子得点 1.0 周 辺に集中して打り，これから逸脱するものは（た とえば, -1.0 以下にあるものは）少数にすぎな い.これらの中には, 散在病巣性失語例 3 例（こ のタイプの $60 \%$ を占める）のほかに, 構音失行 を伴ら失語の重症例が含まれているが，いずれの 場合も因子の変動（改善）がほとんど認められな い.なお，全失語 5 例はすべて -1.0 以上の正常 域にあり，この因子の異常が必ずしも全失語の必 要条件ではないことをあらわしている郝䛨4).

以上，5つの因子が抢のおの示す経時的変動 を，各因子ごとに検討してきた．次に問題の焦点 を個々の症例に移し，そこにみられる5 個の因子 の相互関係とそのパターンを吟味する.

\section{6. 個々の症例の検討}

図 $3(\mathrm{a}) \sim(\mathrm{e})$ は，表 1 にあげた 5 つの臨床タイ プを代表する比較的典型的な例について，その拈 のおのが示寸変動パターンを図示したものであ る（縦軸は因子得点，横軸は経過月数）

まず，単純失語の 4 例についてみると（図 3 a)，第 1 因子（言語行動の一般因子）とその他の 因子とが拈の技の明確に異なる対称的な変動パタ ーンを示すことが明らかである。すなわち，

脚注 4 )

なお, 第 1 部の被験者総数 269 例中第 2 部で追跡 することができなかった 197 例についてみると，こ の第 5 因子に -3.0 以下の明らかな異常を示した例 が合計 12 例あり, その中の 10 例までが, 散在病巣 性失語例と全失語例で占められていた。 
第 1 因子の場合は, 初診時の得点が症例によって 高低まちまちであるにもかかわらず，時間の経過 とともに，いずれも急激な上昇傾向を示している のに対し, (2) 第 2 因子以下は, 初診時の得点 がいずれも 0.0 の周辺に集中し，しかも追跡期間 を通じてほとんど変動がみられない。

このようなパターンの特徵は, このタイプに属 する患者の実際の臨床像とも, きわめてよく一致 している. 寸なわち, 単純失語の分類基準である 2 つの条件，（1）一般的な言語機能の低下一お そらく，第 1 因子によって代表されているような プロセスの障害一を主症状とし，（2）個別的な 失認, 失行, dysarthria など一未そらく, 第 2 因 子以下によって代表されている障害一を合併しな いといら 2 条件を満足させ，同時に，予後に関す る推測（この場合は予後良好の推測）をも実現し ていることがわかる.

これに対して，構音失行を伴ら失語を示す 2 例 の変動パターン（図 3 b) の特徵は, (1) 第 1 因 子と第 3 因子（構音運動のプログラミング）と が，他の因子に比べて著明に低い得点を示してい ること（これに対して，第 2 因子と第 4 因子，す なわち刺激の知覚面に関与する因子がほぼ正常域 にあることに注目), さらに，(2) 時間の経過に つれて，これら 2 つ因子（第 1 因子と第 3 因 子）がほぼ平行関係を保ちながらゆるやかな上昇 傾向を示していることの 2 点であろら.

そしてこの場合も, このような変動パターンの 特徴は, この臨床タイプに属する症例, すなわち 構音失行を伴う失語症例の臨床像（予後を含めて の）とよく一致している.

次の部分的聴覚失認を伴ら失語 2 例の変動パタ ーン（図 $3 \mathrm{c}$ ) は,（1）第 1 因子と第 4 因子（中 枢性聴覚過程）の得点が, 他の因子のそれに比べ て顕著に低く，乙かも（2）その上昇の幅がきわ めて小さいことを特徵としている（これに対し て, 第 3 因子と第 5 因子, 寸なわち, 音声器官の 運動面に関与する因子が, ほぼ正常域にあること に注目).

これらの特徴が，このタイプに属する症例の実 際の臨床像を如実に反映していることは, 前出の 2 つの臨床タイプの場合と同様である.
散在病巣性失語 2 例と全失語 1 例の パターン は，図 3 (d)，(e) に示すと打りである。この場合 も, これらのタイプに属する症例が示す臨床像の 特徵をきわめて適確にあらわしている.

すなわち, 前者散在病巣性失語 2 例においては 第 2 因子（中枢性視覚過程）の低下がきわだち， 第 5 因子（音声器官の運動機能）がこれに続く. これに対して第 1 因子（言語行動の一般因子） は，比較的軽症な範囲にあるにもかかわらず，そ の変動の方向が上昇傾向を示さず，むしろ，下降 する傾向を示している.

一方，後者，すなわち全失語例においては，第 1 因子がもっとも重篤に障害され，しかも経時的 変動がほとんどみられないのに対し，第 2 因子 （中枢性視覚過程）と第 5 因子（音声器官の運動 機能）は，いずれも比較的正常に近い值を保って いる（すなわち，第 2 因子と第 5 因子によって代 表される機能の障害が，必ずしも全失語の必要条 件ではないことを示している.)

以上, 個々の症例における 5 個の因子の変動パ ターンの検討をとおして, Schuell の分類に基つ く5つの臨床タイプが，それぞれ異なる特徵的な パターンを示すことが明らかにされた。

言いかえると，このことは，個々の症例にみら れる 5 個の因子得点の変動パターンが, 実際の臨 床像ときわめてよく一致することを意味し，した がってこれら変動パターンの特徵から, 逆に, 個 々の症例の臨床タイプと予後とを推測することの 可能性を示唆しているといえよう.

\section{IV. 考 察}

第 2 部では，失語症状の経時的変化を 5 個の因 子の変動としてとらえ, 失語症の臨床タイプと発 症からの経過月数とをおもな関係要因として検討 した。しかし, 失語症状の回復と関連の深い要因 として従来から指摘されているものはこのほかに も多数あり，その中には，たとえば大脳の損傷部 位と範囲のほかに，患者の年噛，教育レベル，言 語訓練の開始時期とその内容なども含まれる.

これらのらち，患者の年齢と改善過程との関係 については, 本研究と同じ被験者群を用いて行な った稲枝らの研究報告（1971）がある，かれら 


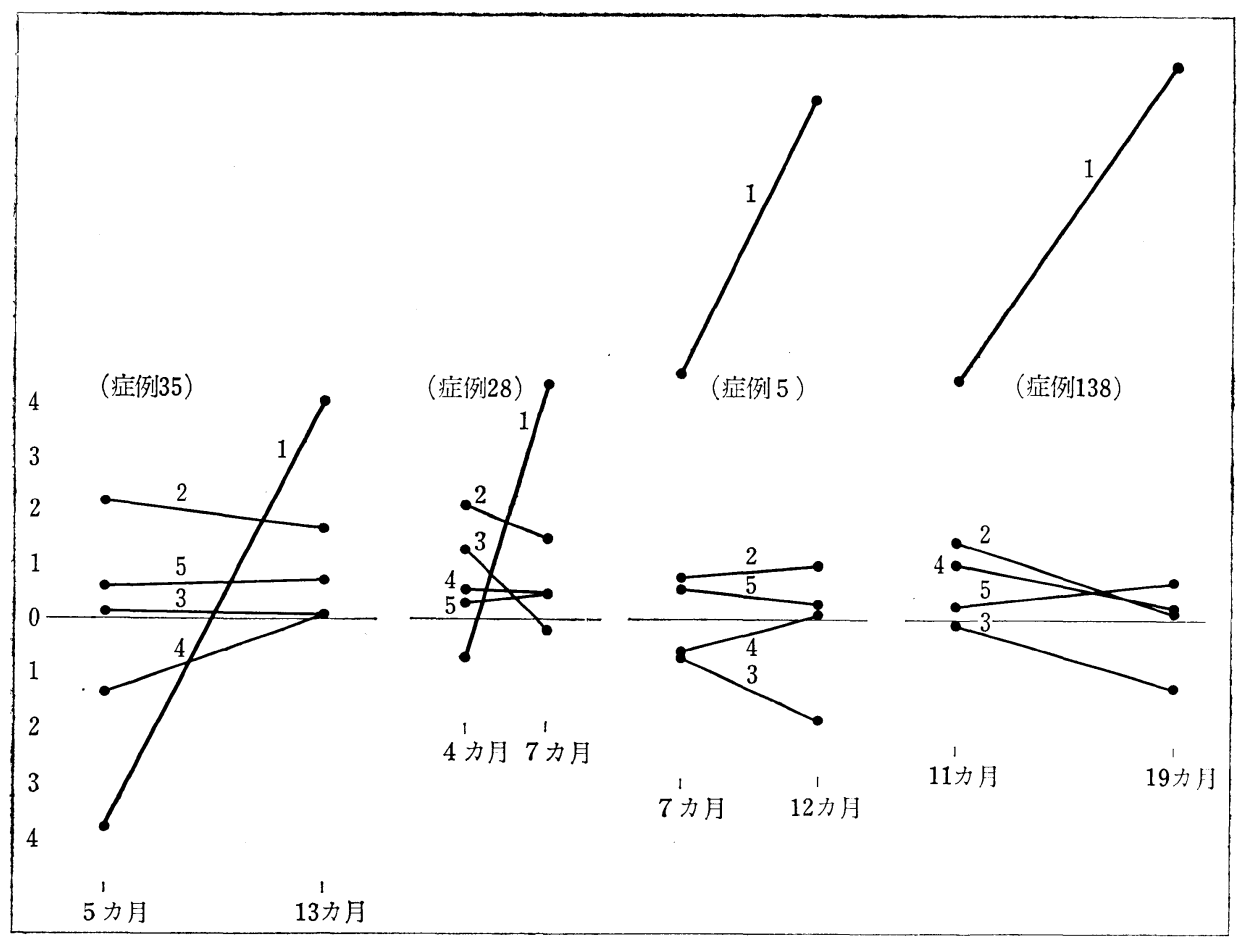

図 3 (a)

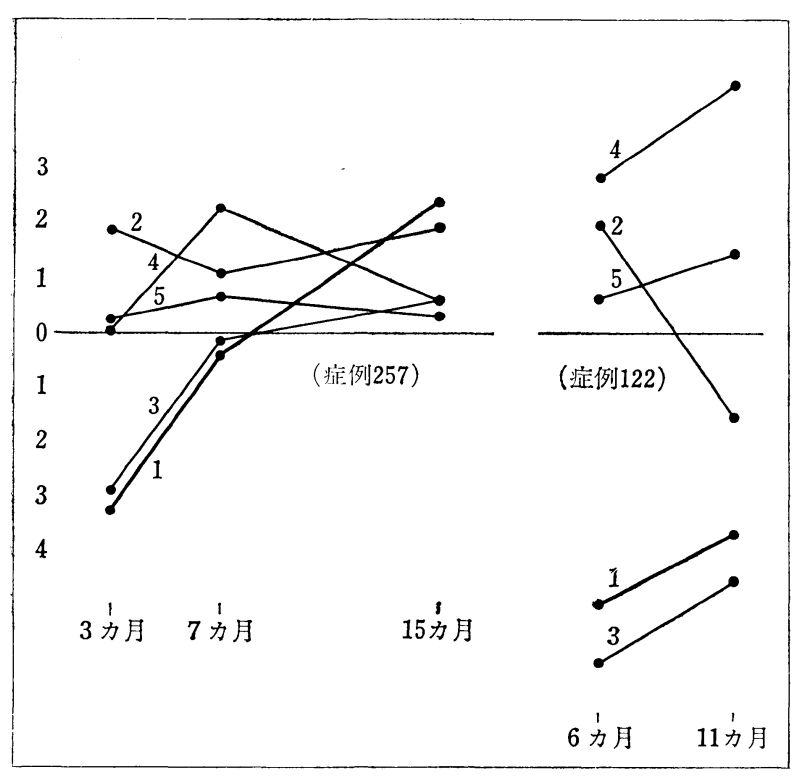

図 3 (b)

は, Schuell-笹沼失語症鑑別診断検查（試案 II）の 各下位検査から得た得点そのものの変動を追らこ とによって，失語症の回復過程の分析を試みてお
り，その結果，高齢者（50歳台以上）の 改善率は若年者（40 歳台以下）のそれに 比べて有意に劣ることを明らかにしてい る（これは Sands ら 1969，の報告と一 致する)。な拉，教育レベルと改善率と の間には，特定の関係が認められなかっ た。

言語訓練の内容（具体的な治療法の種 類とその実施期間，治療頻度など訓練の 質量両面を含む）と失語症状の改善との 関係を探る実験的な研究は，残念ながら ほとんど見当たらず，唯一の例外は， Sarno ら（1970 a）の報告にすぎない. その最大の理由は, 言語治療の質と量と に関するさまざをな要因と，個体側の種 々の条件（自然治癒も含めて）とを厳密 な意味で統制することが，実際上きわめ て困難なことである．今後に残された大 きな課題であろう.

なお，治療の開始までの経過期間の問題につい ては, 本研究の被験者の大多数が第 1 回の検査終 


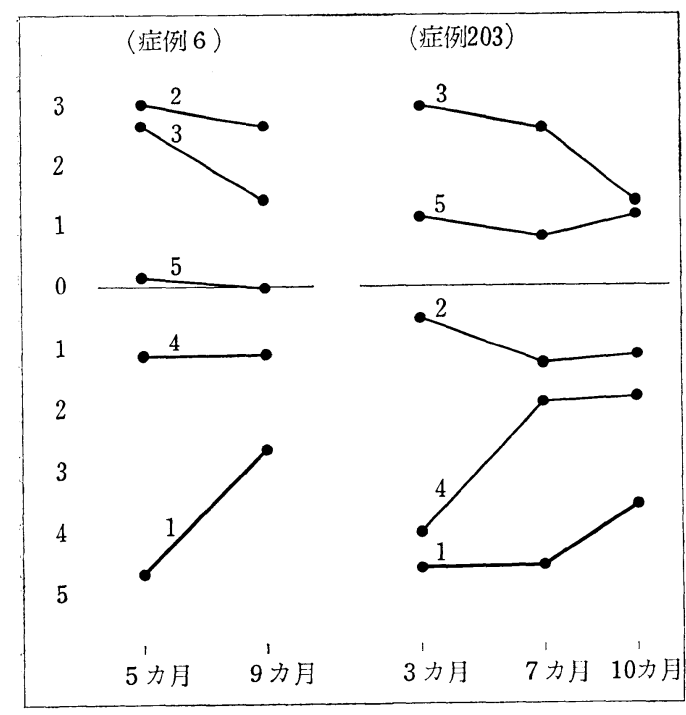

図 3 (c)

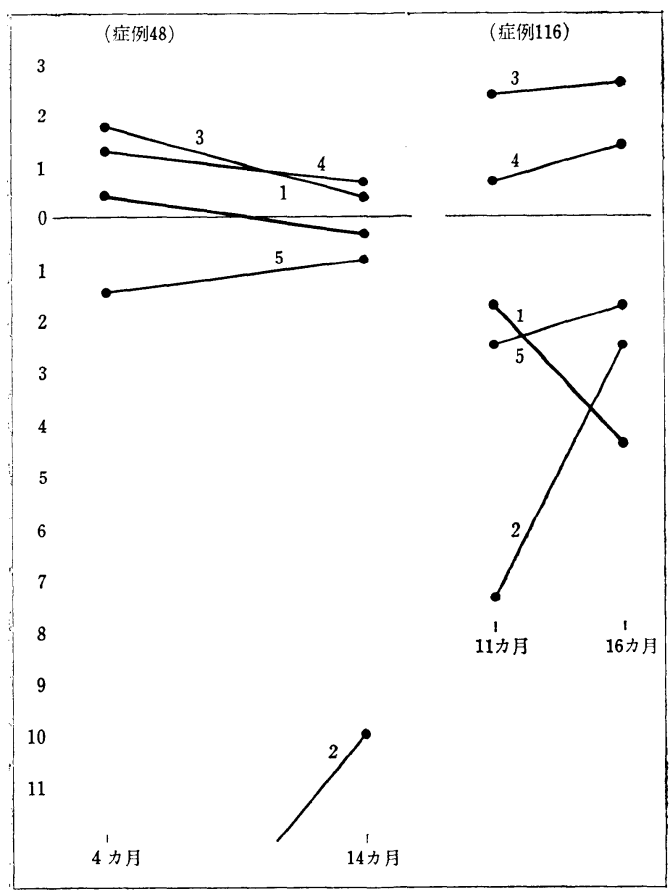

図 $3(d)$

了とほとんど同時に治療を開始しているので，今 回得られたデータになんらかのかたちで反映され ているとみてよいであろら。すなわち, たとえ ば発症後の経過期間が 1 年以内の場合のほうが, 1 年以上の場合に比べて改善率がよいといら傾向 がデータの 1 部として明らかにされているが，こ

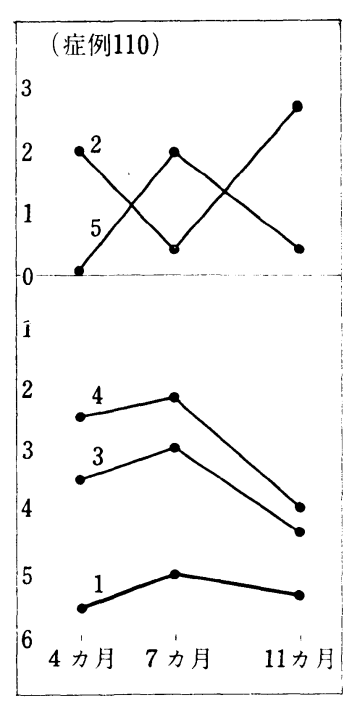

図 $3(\mathrm{e})$

* 折れ線上の数字 $1 \sim 5$ は，それぞれ第 1 因子〜第 5 因子をあらわす。

のことの理由として（もし他の条件が同じであっ たと仮定するならば）自然治癒の要因以外に治療 の早期開始の効果をも無視しえないであろう。た だし，これを実証するためには，上記のような困 難な問題をかかえた実験的研究に頼ら将ばならな いことは言うまでもない。

\section{問 題 点}

第 2 部の追跡研究をと抢して，第 1 因子（言語 機能の一般因子）が失語症の回復過程をもっとも 敏感に反映する因子，いわば回復過程の実態を知 るための鍵であることがいっそら明確にされた。

しかし問題は，この因子が，言語行動 (language behavior）というきわめて包括的な能力をあらわ していることである. 臨床的にわれわれがもっと も知りたいことがらの一つは, 個々の症例におい て，このような言語行動のどの側面が，どのよう な順序で, どの程度まで変わりらるかということ の見通しであるが，今回われわれの用いた因子変 動の追跡といら方法をもってしては，この因子の もつ包括的な性質上, そのような情報は得られよ らもない。この点についての部分的な解答を与え るものとしては, 前述の稲枝ら(1971)の結果があ る. すなわち, かれらは, 個々の患者にとって障 害のもっとも軽度である modality が，その他の 
modality に比べてょり早く改善するという一般 的な傾向が認められることを明らかにしている。 その例としてかれらは，たと党ば構音失行を伴ら 失語症患者の場合は, 聞く modality と読む modality の改善が先行し, 話す modality の改善が 遅れるといら現象をとりあげ, 各臨床タイプに特 有な改善のパターンが認められることを指摘して いるが，この点は，今回の追跡研究の結果とも一 致している（すなわち，個々の症例においてその 鑑別診断の条件となっている個別的な障害が，他 の因子に比べて改善しがたいという傾向として示 されている).

こうした情報ももとより重要ではあるが，しか し，ここには, 個々の患者に対する個別的な言語 治療プログラム中に指定すべき詳細かつ具体的な 手順ないし方法（特定の言語症状のどの側面につ いて，どういう種類の刺激・強化をどのようなス ケジュールで与えるか; たとえば, 単語の回収機 能と構文機能とのどちらを先にとりあげ，どのよ らな品詞を，または文型を，どういう順序で，ど らいう脈絡の中で与えるかなど）を示唆しうる掘 下げた情報は含まれていない、つまり, 現在われ われが行なっている言語症状の評価ないし分析法 は，こうした目的にかならような十分な精密さと 鑑別力とをそなえていないといつてよい.

その意味で, 第 1 部の<考察>ですでに指摘し たよらな方向へ，今後の研究活動を進めることの 必要性が，ここでも再び強調されるべきであろ 5 .

\section{因子構造の神経生理学的基礎}

今回の解析によって得られた因子構造の神経生 理学的解釈については, 第 1 部ですでに触れた が, 第 2 部の追跡研究をとおして, このよらな解 釈の妥当性がさらに支持されたといってょかろ う.すなわち， 5 個の因子中, 失語症状の経時的 変化, ないし改善過程をもっとも敏感に反映する ものが第 1 因子（言語機能の一般因子）であるこ とが明らかにされた。そしてこの事実は，（1）

第 1 因子によって代表される 言語過程 (language processes), ないし Wepman のいら統合機能 (integrative function) が, 第 2 因子以下によって代 表されるものに比べて,より複雑な線維連絡に依
存する非特異的 (non-specific) なプロセスである こと，したがって，（2）いったん損傷を受けた 場合に, 神経生理学的なく機能の再編成>の行な われる可能性がより多く残されており, 外的環境 からの適切な刺激（たと光ば言語訓練）が，この 再編成の過程に寄与しらる余地もそれだけ大きい ことなどを意味していると考えられる。

これに対して，第 2 因子以下によって代表され るものは,より特異的 (specific) なプロセスと考 えられ，したがって，そうしたものの障害に対す る神経生理学的代償力も，ょり強い制約を受ける （すなわち，＜機能の再編成>の可能性がより少 ない）とみてょいであろら。

いずれにしても，このような推測を推測のまま にとどめず，実際のデータによって裏づける手だ てを講ずることが今後に残された課題であろう.

\section{V. 総 括}

本研究第 1 部の被験者 269 例中 72 例について, 失語症状の経過を 5 個の因子得点の変動として追 跡し, 以下の結果を得た.

（1）個々の因子別経過観察によると, 症状の 推移に伴い各因子がそれぞれ特徴のある変動を示 した.

（2）第 1 因子は, 失語症状の回復過程をもっ とも敏感に反映する因子であった。すなわち，初 診時には汪とんど例外なく異常域にあったが，そ の後の変動（改善）の幅が大きく，しかも，その 変動が長期（発症後 1.5 年）にわたって続く傾向 を示した。

（3）これに対して第 2 因子以下は，それぞれ 特定の症例についてのみ異常を示し, また変動の 幅が狭く, 変動の存続期間も短かかった。

(4) 個々の症例別に 5 個の因子の変動パタ一 ンを検討すると, Schuell の分類に基づく 5 つの 臨床タイプに属する症例群が，それぞれ異なる特 有のパターンを示した.

（5）これらの結果は, 各因子の神経生理学的 解釈を支持するものと思われた。 なおこうした 解釈の客観的な裏づけを得るための方法を講じる ことが今後の問題として指摘された. 
(本研究の被験者 269 例の言語検査ならびにその結果の 整理に多くの時間と労力とを注き込まれた鹿教湯温泉療 養所言語訓練室の職員諸氏, 当時の所長として種々のご 便宜をはかられた福井图彦博士，および現所長藤田勉博 土に対し心からの感謝をささげます.

さらに，本研究のデータ計算にご助力いただいた東京 大学医学部保健学科柳井春夫博士, 本論文の執筆過程で 種々の貴重なご意見を賜わった東京大学医学部音声言語 研究施設 藤村靖教授に対し，深くお礼申し上げます).

\section{文 献}

1) Sands, E. Sarno, M. T., and Shankweiler, D. : Long term assessment of language function in aphasia due to stroke. Arch. Phys. Med., 50 : 202-207, 1969.

2) Sarno, M. T., Silverman, M., and Sands, E.: Speech therapy and recovery from severe aphasia. J. Speech Hearing Res., 13:607623, 1970 a.
3) Sarno, M. T., Silverman, M., and Levita, E.: Psychosocial factors and recovery in geriatric patients with severe aphasia. J. Amer. Geriat. Soc., $18: 405-409,1970$ b.

4) Sarno, M.T., and Levita, E. : Natural course of recovery in severe aphasia. Arch. Phys. Med., 52 : 175-179, 1971.

5) Schuell, Hildred, Jenkins, J.J., and JimenezPabon, E.: Aphasia in Adults ; Diagnosis, Prognosis and Treatment. New-York, Hoeber, 1964.

6) Vignolo, L. A. : Evolution of aphasia and language rehabilitation; Retrospective exploratory study. Cortex, $1: 344-367,1964$.

7) 稲枝道子, 笹沼澄子, 竹内愛子, 物井寿子, 待 岡庸子: Schuell-笹沼失語症検查得点にみる 改 善過程の分析. リハビリテーション医学, 8: 237-238, 1971.

ロ訂正とお詑び

前号 9 巻 1 号に所載の笹沼論文に以下のような誤りがありましたので, 訂正しお詑び申しあげ ます。

p 21 福迫 1970 $\rightarrow$ 福迫 1969, p 25 回収能力を $\rightarrow$ 回収能力に, p 29 (表中) $265 \rightarrow 269$

p 32 （2）新たに実験を計画された $\rightarrow(2)$ 新たに計画された

p 32 因子が 2 個の分離されて $\rightarrow$ 因子が 2 個分離されて

(「リハビリテーション医学編集室)

\section{急性一酸化炭素中毒}

新 刊

安河内五郎 大牛田労災療養所長

A5 頁132 図18 写真23 $1972 \quad ¥ 2,200 \quad$ \%110

CO中毒の診断と治痖, リハビリテーションを臨床経験を基に解説

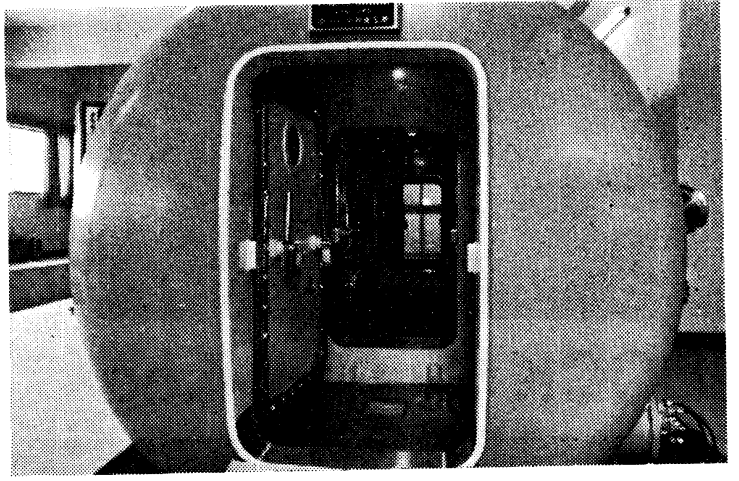

図32 高圧酸素治療室 (九州学災病院設置)
本書は一酸化炭素中毒に関する実地医家のための解説書。 1963年11月におこつた三井三池炭坑のカス爆発を契機とし て, 専門医学的立場から C O 中毒患者の診断と治療, およ び社会復帰訓練などにあたつた著者が，臨床における多く の経験を基にしてまとめたもの。実験的研究所見をも加え 説明し，さらに従来の内外の諸報告をも集録した。

\section{[主要内容]}

緒言 /一酸化炭素カス/一酸化炭素中毒の機序／病理解剖 /臨床症状（前駆期・極期・いわゆる間歇型について・回 復期・䠛床検査所見）／経過と予後／後遺症／診断／治療 （急性期の治療・回復期の治療）／慢性一酸化炭素中毒／ 付・三池炭坑災害一酸化炭素中毒者の社会復帰について 